DOI https://doi.org/10.30525/978-9934-588-80-8-2.38

\title{
ВИКОРИСТАННЯ ІННОВАЦІЙНИХ ПЕДАГОГІЧНИХ ТЕХНОЛОГІЙ У ПРОФЕСІЙНІЙ ОСВІТІ
}

\author{
Колесник О. В. \\ викладач вищуої категорії, \\ викладач комісії правових дисииплін \\ Романюк О. М. \\ викладач вищої категорії, старший учитель, \\ викладач сочіальних дисичиллін \\ Вінницький технічний коледж \\ Голсва Т. В. \\ викладач I категорії, \\ викладач сочіальних дисциплін \\ Вінницький технічний коледж \\ м. Вінниця, Україна
}

Вінниџький фаховий коледж економіки та підприємництва ЗУНУ

Переосмислення пріоритетів підготовки фахівців відповідно до запитів суспільства визначає актуальність проблеми забезпечення якості професійної освіти. У даний час у науці складається концепція нової цивілізації - цивілізації якості. Забезпечення якості стає ключовою ідеєю та новою філософією освіти, а управління якістю освітньої діяльності - комплексною педагогічною проблемою.

Здатність мобілізувати знання, вміння та досвід у конкретній соціально-професійній ситуації характеризує компетенцію професійно успішної особистості. Інтеграційна природа освітнього середовища обумовлена динамічною рівновагою об'єктивних процесів інтеграції та диференціації, яка характерна для соціальних явищ і розвитку науки в цілому $[1$, с. 3$]$.

У філософському аспекті справжнє пізнання нерозривно пов'язане 3 інтегрованістю, що сприяє цілісному пізнанню буття. Інтегрованість як найважливіша характеристика освітнього середовища обумовлює іiі взаємодоповнюючі властивості багатовимірності та єдності.

Основу методологічного рівня інтеграції освітнього середовища становить синтез системного, діяльнісного, еколого-психологічного, компетентнісного підходів. Функціонування даних підходів розуміється в сукупності, що дозволяє уявити інтегративне освітнє середовище як 146 
цілісну систему, яка визначає процес професійного розвитку студентів [2, c. 114].

Освітнє середовище конкретного навчального закладу професійної освіти включає мікросередовища функціонування структурних підрозділів, навчальних аудиторій та лабораторій, окремих викладачів. Освітні середовища різних рівнів організації взаємодіють між собою, розширюючи можливості професійного навчання студентів.

Змістовний рівень інтеграції освітнього середовища організований як об'єднання варіативних можливостей навчальних i розвиваючих ресурсів, зв'язки й відносини між якими мають кооперуючий характер. Можливості професійного навчання значно доповнюють ресурси інформаційних освітніх середовищ. Дані середовища забезпечують використання сучасних інформаційно-комунікаційних технологій та здійснення переходу до відкритої освітньої системи [3, с. 7].

Інтеграційне освітнє середовище у взаємозв'язку утворюює структурно-функціональні компоненти, що впливають як єдине ціле на процес навчання і особистісно-професійний розвиток студентів. Дане освітне середовище реалізує адаптивну функцію, засновану на розумінні адаптації як внутрішнього прагнення людини до розвитку, його здатності пристосуватися до мінливих умов середовища [4, с. 131-132].

Пошук шляхів підвищення якості підготовки фахівців обумовлює вдосконалення технологій, форм і методів навчання, які підвищують ефективність використання варіативних можливостей навчальних i розвиваючих ресурсів інтегративного освітнього середовища. Відповідно до вимог реалізації основних професійних освітніх програм, освітня установа має передбачати використання активних та інтерактивних форм проведення навчальних занять у поєднанні 3 позааудиторною роботою для розвитку загальних i професійних компетенцій студентів [5, с. 132].

Сутність використовуваних в освіті педагогічних технологій найбільш точно відображає процесуальний підхід, який визначає даний феномен як системний спосіб побудови педагогічного процесу в певній послідовності дій, операцій і процедур, що забезпечують досягнення прогнозованого результату Технологія навчання - варіативна, дидактична складова педагогічної технології, спосіб реалізації змісту навчання, передбаченого навчальними програмами. Технологія навчання являє собою систему форм, прийомів і засобів навчання, що забезпечує найбільш ефективне досягнення поставлених цілей. Окремі елементи методики або окремо взяті педагогічні прийоми не $\epsilon$ технологіями навчання [6, с. 111]. 
Впровадження нових технологій навчання - це інноваційний процес, він підпорядковується всім правилам інноваційної діяльності по перетворенню педагогічного процесу, впровадження нововведень, спрямованих на його вдосконалення. Більшість дослідників визначають інноваційні процеси в освіті як систему, яка активно відгукується на виклики соціокультурної реальності і не відкидає існуючих традицій, вносить принципові зміни в навчання, виховання $\mathrm{i}$ розвиток особистості [7, с. 85$]$.

Інноваційні технології навчання, спрямовані на розвиток загальних і професійних компетенцій навчання дозволяють використовувати варіативні освітні можливості інтегративного освітнього середовища ВНЗ є проектно-дослідницька технологія, технологія розвитку критичного мислення, кейс-технологія, технологія портфоліо, технологія навчальних питань, модульно-рейтингова система навчання, інформаційно-комунікаційні технології та інші. Дані педагогічні технології в поєднанні $з$ лекційно-семінарською методикою навчання оптимально забезпечують досягнення цілей професійної освіти та підвищення іiі якості. Компетентнісно-орієнтовані педагогічні технології є інноваційними, так як відповідають цілям інноваційних перетворень: за допомогою їх використання в освітній процес впроваджуються нововведення, що сприяють вирішенню стратегічних завдань соціальноекономічного розвитку суспільства [4, с. 132].

Вибір технологій навчання залежить від цілей освіти, специфіки змісту навчального матеріалу, рівня розвитку і підготовленості дітей, мотивації навчальної діяльності та спрямованості інтересів, кількості студентів, їх віку, технічного оснащення освітнього процесу. Аналіз досвіду педагогічної діяльності дозволяе зробити висновок про ефективність застосування у викладанні технології розвитку критичного мислення та проектно-дослідницької технології.

Дані технології спрямовані на розвиток як загальних, так i професійних компетенцій студентів в умовах інтегративного освітнього середовища:

- вирішувати проблеми, оцінювати ризики та приймати рішення в нестандартних ситуаціях;

- здійснювати пошук, аналіз і оцінку інформації, необхідної для вирішення професійних завдань, особистісно-професійного розвитку;

- використовувати інформаційно-комунікаційні технології для вдосконалення професійної діяльності [2, с. 117].

Результати дослідно-експериментальної діяльності з впровадження інноваційних педагогічних технологій в освітній процес навчальних закладів професійної освіти дозволяють констатувати такі зміни, як 148 
підвищення якості освітніх послуг, зростання професійної майстерності педагогів, розвиток позитивного ставлення студентів до навчання, їх творчого потенціалу та мобільності, що в сукупності визначає підвищення конкурентоспроможності випускників.

\section{Література:}

1. Артюх В. О. Соціальна філософія. Історія, теорія, методологія: матеріали доповідей та виступів Міжнародної науково-теоретичної конференції, м. Суми, 19-20 квітня 2017 р. / Ред.кол.: С. О. Лебідь, А. С. Лебідь. Суми: СумДУ, 2013. С. 3-9.

2. Бабка В. Л. Теоретичні та методичні засади навчання педагогічно обдарованих студентів: Науковий збірник / За заг. ред. М. О. Фролова. Запоріжжя: Інтер-М, 2016. С. 113-118.

3. Буряк Л. І. Особистісно орієнтоване виховання. Гілея: науковий вісник. 2015. № 72. С. 5-12.

4. Вишняк О. Естетичне виховання і гуманізація особи / За ред. В. Ворони, М. Шульги. Вип. 2 (16). Київ: Інститут соціології НАН України, 2018. С. 129-139.

5. Герасименко Л. С. Партнерство школи, сім’ї та органів самоорганізації населення у справі соціалізації молоді 2013. Вип. 1. C. $116-134$.

6. Гирич І., Шаповал Ю. Проблема формування моральних цінностей майбутніх учителів. Інклюзивна освіта. - Київ : І3МН, 2017. - 128 с.

7. Глушко А. О. Педагогічні дослідження: методологічні поради молодим науковцям. Київ : УАДУ, 2010. - 198 с. 